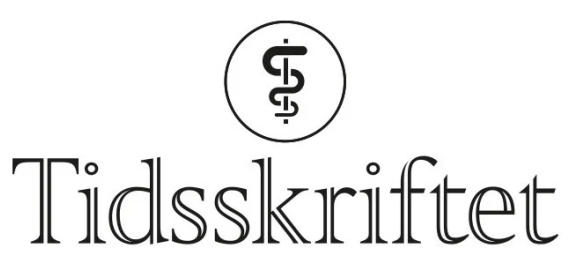

DEN NORSKE LEGEFORENING

\title{
Når spydspissen blir liggjande i skuffen
}

DEBATT

\section{BJØRG BAKKE}

bakkebjorg@gmail.com

Bjørg Bakke er fastlege i Porsanger kommune, Finnmark. Ho er tidlegare leiar av Norsk medisinstudentforening.

Forfattaren har fylt ut ICMJE-skjemaet og oppgir ingen interessekonfliktar.

\section{Å vere lege i norsk helsevesen er risikosport - enten i form av å ikkje få vaksine mot covid-19, slik mange framleis ikkje har fått, eller i form av at vaksinen kan ha gitt verst tenkelege utfall for helsearbeiderar med mange gode leveår føre seg.}

Det har døydd to unge helsearbeidarar i etterkant av AstraZeneca-vaksinering. Undersøkingar så langt har vist at det mest sannsynleg er ein direkte samanheng. Kvifor skal me som helsepersonell i det heile tatt godta å ikkje bli vaksinert under ein pandemi? Kvifor skal me bli tilbode ein vaksine som har vist mykje dårlegare effekt enn andre tilgjengelege vaksinar $(\underline{1}, \underline{2})$ ? Når det i tillegg viser seg at unge helsearbeidarar mest sannsynleg har døydd på grunn av denne vaksinen, så blir situasjonen heilt tragisk.

Som fastlege følgjer eg med på listene og ser fleire gamle, demente og multimorbide pasientar dø nokre veker etter Pfizer-vaksinane sine. Sannsynlegvis har dei ikkje tålt nokre dagar med dårleg matlyst og kvalme. Kva er det me som gruppe driv med? Har me gitt opp å påverke systemet rundt oss med faglege innspel? Er me også blitt så redd døden at me til slutt prioriterer ressursane våre til multimorbide og demente pasientar framfor dei unge generasjonane? Har me gløymt at ein stor del av det å vere lege er å prioritere ressursar?

\section{«Er legestanden så ubetydeleg at midt i ein pandemi er stemma til} foreininga vår redusert til eit knippe Facebook-postar?»

Det sit representantar for legegruppa i etikkrådet, det er legar som styrer våre største sjukehus. Og våre helseføretak, departement og direktorat er fulle av legar og ymse utval for ditt og datt. Me kan vel strengt talt ikkje skulde på at me ikkje er representert? 
Så kvifor er det slik at mange av oss som faktisk jobbar klinisk med legeyrket føler at systemet er i ferd med å kollapse rundt oss? Vilkåra for å gjere ein god jobb som lege er heilt fråverande, og alle som faktisk har ein jobb med påverknad på systemet skuldar berre på den andre parten. Kvifor er Sjukepleiarforbundet ute i media og kondolerer når ein helsearbeidar har døydd (3)? Kvar er Legeforeininga? Er legestanden så ubetydeleg at midt i ein pandemi er stemma til foreininga vår redusert til eit knippe Facebook-postar og hashtags med \#helseførst?

Konklusjonen min er at me må setje ned foten og slutte å akseptere alt me blir tilbode. Utan oss får ingen menneske i Noreg helsehjelp. Så enkelt er det. Du vil få stell av ein sjukepleiar og mat av ein hjelpepleiar, du vil få røntgen og ultralyd, men når dei verkelege problema oppstår, så er det faktisk legestanden som utfører kirurgien, finn diagnose og skriv ut behandling, forløyser bornet eller tolkar komplisert biletdiagnostikk. Det er me som er spydspissen i helsevesenet, og det skal me bruke for det det er verdt.

«Du som betalande medlem kan krevje at representantane skal gjere ein godjobb»

Ja, Legeforeininga er i dialog med dei fleste, men har denne dialogen ført til noko som helst? Er det ikkje på tide å endre denne fastlåste og strengt talt feilslåtte strategien? Kva skjer med vaksinar til legar og helsepersonell under pandemien? Kva skjer med handlingsplanen for fastlegeordninga? Kva skjer med legevakt i Rikslønnsnemnda? Kva skjer med arbeidsvilkåra på sjukehus? Vilkåra våre blir ikkje betre, men dag for dag verre. Me må endre taktikk og bruke den nøtta som fekk oss gjennom vidaregåande og medisinstudiet, til noko fornuftig.

Kva er så løysinga? Me må i alle fall bruke organisasjonen vår meir hensiktsmessig enn me gjer i dag. Kanskje det ikkje er lett, kanskje det er umogleg, men å gjere ingenting får oss ingenstad! Det er val i Legeforeininga i vår. Mest sannsynleg blir det nokon som har vore der i mange år før, og politikken som blir vedtatt, blir ganske lik som tidlegare. Men det kan medlemmane endre på ved å delta på landsmøtet! Ikkje la dei valde representantane eller tillitsvalde møte dykk med at «alle som vil, kan stille» eller «viss du er misnøgd med jobben, kan du stille sjølv» Det er feil! Du som betalande medlem kan krevje at representantane skal gjere ein god jobb. Delta på landsmøtet og vis at du bryr deg!

\section{LITTERATUR}

1. Polack FP, Thomas SJ, Kitchin N et al. Safety and efficacy of the BNT162b2 mRNA Covid-19 vaccine. N Engl J Med 2020;383: 2603-15. [PubMed][CrossRef]

2. Knoll MD, Wonodi C. Oxford-AstraZeneca COVID-19 vaccine efficacy. Lancet 2021;397: 72-4. [PubMed][CrossRef]

3. Nave B. Lederen i Norsk Sykepleieforbund: Vi kondolerer til familien. VG 15.3.2021. https://direkte.vg.no/nyhetsdognet/news/leder-i-norsk-sykepleierforbund-vi-kondolerer-til-familien.Hz2r3Y2T Lest 21.3.2021.

Publisert: 26. mars 2021. Tidsskr Nor Legeforen. DOI: 10.4045/tidsskr.21.0212

Mottatt 17.3.2021, godkjent 24.3.2021.

(C) Tidsskrift for Den norske legeforening 2023. Lastet ned fra tidsskriftet.no 26. april 2023. 